\title{
Desain Amplifier Gitar Berbasis Material Rotan
}

\author{
Farhannurmaris Karel Saputra dan Agus Windharto \\ Departemen Desain Produk Industri, Fakultas Teknik Sipil dan Perencanaan, Institut Teknologi Sepuluh Nopember \\ (ITS) \\ e-mail: aguswind@prodes.its.ac.id
}

\begin{abstract}
Abstrak - Indonesia merupakan negara penghasil rotan terbesar di dunia, diperkirakan $85 \%$ bahan baku rotan di seluruh dunia dihasilkan oleh Indonesia . Kekayaan material rotan kurang dimanfaatkan oleh negeri sendiri, meskipun telah ada kebijakan pemerintah yang melarang ekspor bahan baku rotan. Tingginya minat dari pasar terhadap produk rotan membuat banyaknya upaya inovasi dan eksplorasi yang dilakukan pada material rotan itu sendiri tidak hanya menjadikan produk furnitur tetapi juga menjadi produk yang lain. Alat musik yang kebanyakan menggunakan bahan kayu, dapat menjadi produk desain yang inovatif dengan rotan sebagai bahan alternatif pengganti kayu. Beberapa alat musik yang memungkinkan di eksplor dengan material rotan diantaranya gitar, bass, drum, dan amplifier. Keberadaan pengrajin amplifier lokal dengan skala kecil atau rumahan hingga industri menengah perlu diberikan apresiasi. Maka perlu dilakukan upcycle dari amplifier lokal guna meningkatkan inovasi produk. Pada akhir penelitian ini, dihasilkan beberapa varian desain baik dari segi bentuk maupun ukuran dari amplifier berbahan dasar rotan. Desain baru yang dihasilkan memberikan kesan baru dari segi desain dan memiliki komposisi bentuk baru yang tergolong menarik secara pasar.
\end{abstract}

Kata Kunci- Rotan, Amplifier Gitar, Innovation Product

\section{PENDAHULUAN}

$\mathrm{I}$ NDONESIA merupakan negara penghasil rotan terbesar di dunia, diperkirakan $85 \%$ bahan baku rotan di seluruh dunia dihasilkan oleh Indonesia, sisanya dihasilkan oleh Negara lain seperti : Philippina, Vietnam dan negara-negara Asia lainnya. Daerah penghasil rotan yaitu P. Kalimantan, P. Sumatera, P. Sulawesi dan P. Papua dengan potensi rotan Indonesia sekitar 622.000 ton/Tahun. Pasar internasional memiliki minat yang sangat tinggi pada produk berbahan dasar rotan

Pemanfaatan material rotan pada umumnya digunakan sebagai bahan baku pembuatan produk furnitur dan produkproduk kerajinan. Melihat potensi dari material ini, rotan memiliki nilai strategis dalam perkembangan industri kreatif di Indonesia.

Tingginya minat dari pasar terhadap produk rotan membuat banyaknya upaya inovasi dan eksplorasi yang dilakukan pada material rotan itu sendiri. Alat musik yang kebanyakan menggunakan bahan kayu, dapat menjadi produk desain yang inovatif dengan rotan sebagai bahan alternatif pengganti kayu. Beberapa alat musik yang memungkinkan di eksplor dengan material rotan diantaranya gitar, bass, drum, dan amplifier.

Keberadaan pengrajin amplifier lokal dengan skala kecil atau rumahan hingga industri menengah perlu diberikan apresiasi, namun eksplorasi penelitian terhadap rotan sebagai bahan baku case amplifier itu sendiri dirasa belum banyak dan belum pernah dilakukan. Maka dari itu perlu dilakukan upcycle dari amplifier lokal guna meningkatkan inovasi produk dari amplifier lokal sehingga tidak hanya menunjang kebutuhan dalam bermusik, tapi juga menunjang fitur dan life style yang lebih menarik.

Amplifier gitar pada umumnya menggunakan material kayu sebagai case nya. Untuk menilai potensi dari rotan perlu dilakukan data akustik dan kualitas bunyi dari amplifier yang dibuat. Rotan dapat memberikan kebaruan pada material yang digunakan sebagai case, juga dengan karakter dari material rotan yang ringan dan mudah dilengkung dapat memberikan kebaruan bentuk dari amplifier itu sendiri.

\section{URAIAN PENELITIAN}

\section{A. Tahap Pengambilan Data}

Metode pengambilan data diperoleh dari pengumpulan literatur yang terkait dengan penelitian, interview, shadowing kepada user, dan quisioner. Data primer tersebut meliputi; deep interview dengan salah satu produsen amplifier gitar lokal merk "the java amps" di Surabaya Ricky Hermawan, selanjutnya melakukan shadowing pada para soundengineer di sebuah acara kampus agar mengetahui teknik penyimpanan, operasional dan hal-hal yang harus diperhatikan dalam hal teknis.

\section{B. Tahap Studi dan Analisis}

Tahapan studi analisis meliputi bagaimana mengaplikasikan laminasi rotan sebagai bahan pembuatan amplifier gitar, diantaranya:

1. Studi analisis pasar : diperlukan sebagai acuan untuk mengetahui segmentasi dan positioning pasar untuk amplifier rotan yang telah dibuat.

2. Studi eksisting produk : untuk mengetahui proses desain dan eksplorasi material hingga menjadi produk yang ada pada saat ini.

3. Studi bentuk : menentukan bentuk yang berakibat pada karakter suara gitar akustik yang mengacu pada eksisting produk

4. Studi material : untuk mengidentifikasi rotan dalam pembuatan amplifier gitar.

5. Analisis laminasi rotan: menentukan laminasi mana yang akan digunakan sebagai bentukan awal amplifier

6. Analisis proses eksperimen: untuk mengetahui hasil dari rotan yang sudah di proses, agar pada saat proses assembly menjadi produk memiliki kualitas yang baik.

7. Studi warna dan finishing : diperlukan sebagai pertimbangan alternatif warna yang dipilih 
8. Analisis karakter suara akustik rotan: untuk mengetahui karakter akustik dari material rotan itu sendiri.

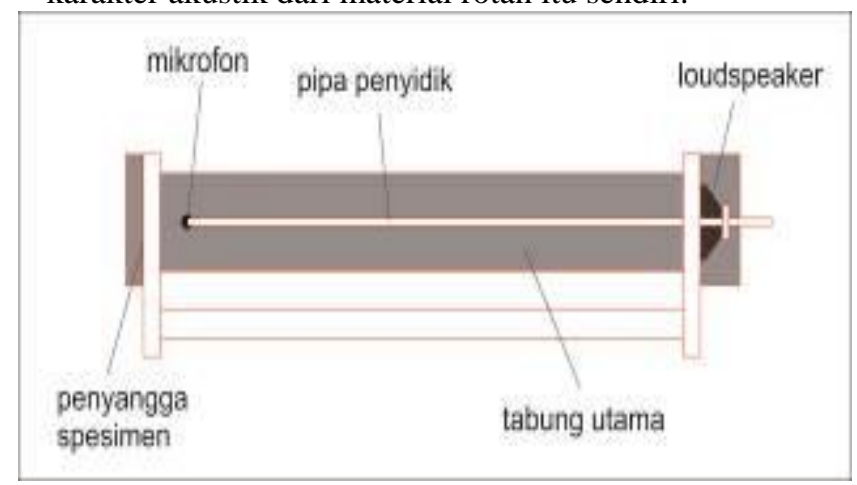

Gambar 1. Skema tabung impedansi.

Analisis ini bertujuan untuk memperoleh data tentang karakteristik material rotan terhadap bunyi atau dalam kaidah fisika disebut koefisien absorbsi $(\alpha)$

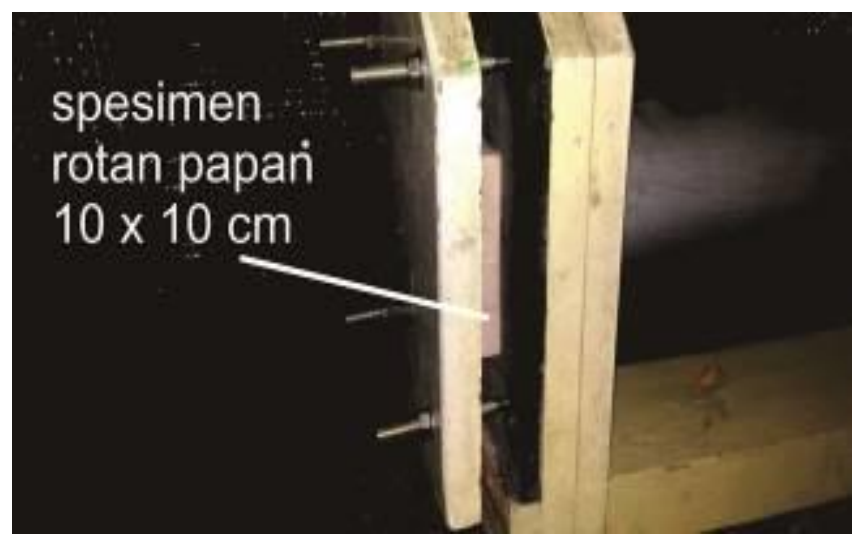

Gambar 2. Spesimen Rotan yang dipasang pada Tabung Impedansi.

Sampel yang digunakan dalam uji ini adalah rotan dengan dimensi $10 \mathrm{~cm}$ x $10 \mathrm{~cm}$ menyesuaikan dengan diameter tabung impedansinya, sehingga apabila diberi gelombang bunyi sampel yang akan terkena langsung dari sumber bunyi.

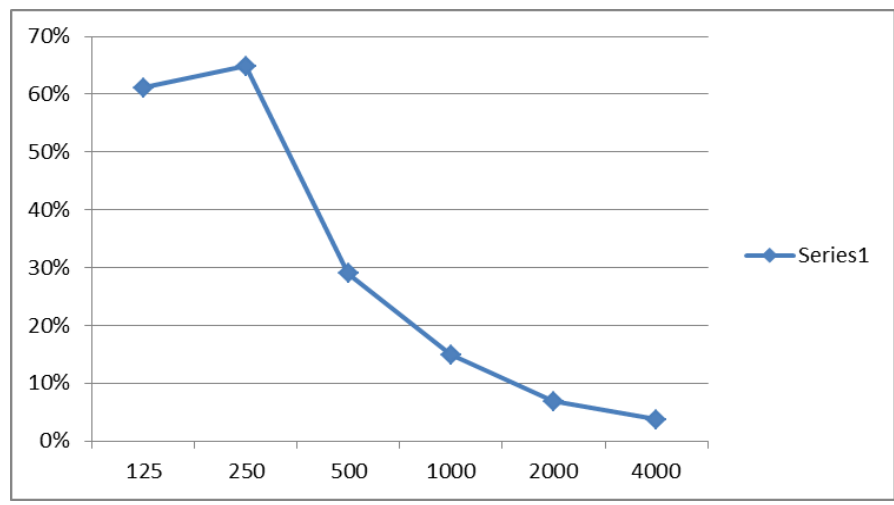

Gambar 3. Grafik hasil analisis koefisien absorbsi akustik pada spesimen rotan.

Kurva koefisien absorbsi yang diperoleh setelah pengujian sampel rotan. Dapat disimpulkan bahwa material rotan lebih mengabsorbsi pada frekuensi rendah $(125 \mathrm{~Hz}-250 \mathrm{~Hz})$ sedangkan pada frekuensi tinggi $(1000-4000 \mathrm{~Hz})$ tingkat absorbsi rotan menurun.

\section{HASIL PENELITIAN}

\section{A. Sketsa dan Alternatif Desain}

Alternatif desain dimulai dari sketsa awal hingga membuat 3d model dengan aplikasi 3ds max.

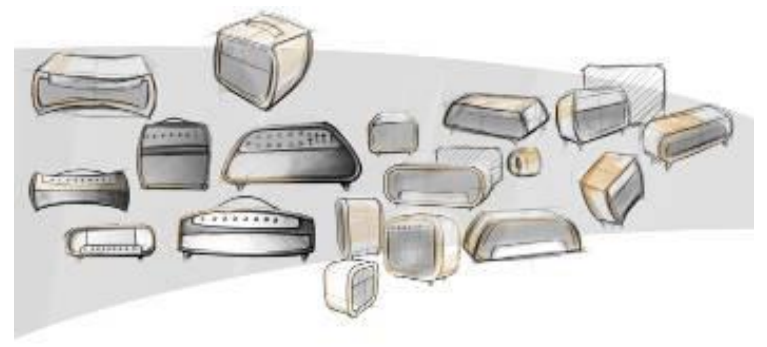

Gambar 4. Sketsa awal desain amplifier.

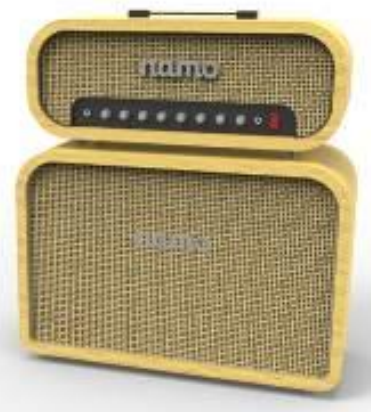

Gambar 5. 3D model desain amplifier rotan.

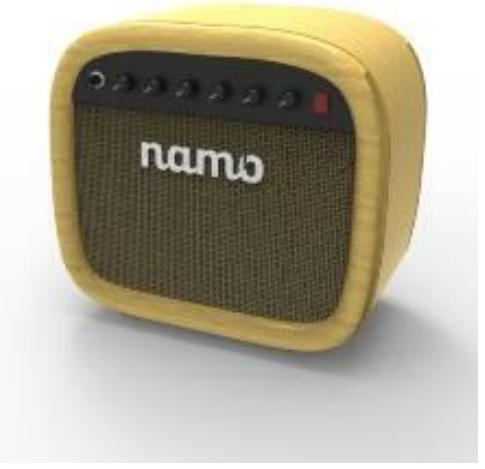

Gambar 6. 3D model desain amplifier rotan.

\section{B. Proses Prototyping}

\section{Eksperimen 1}

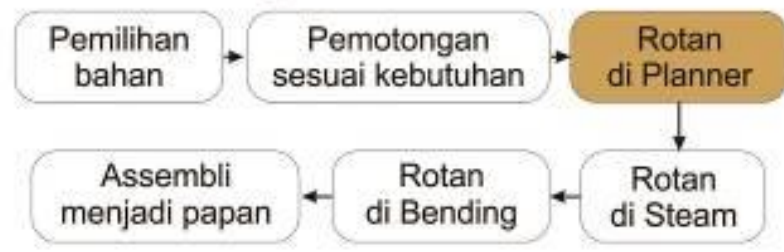

Gambar 7. Eksperimen pembuatan rotan 1. 
Pada proses eksperimen pertama terdapat 7 proses, dimulai dari pemilihan bahan hingga assembly menjadi rotan dan yang terakhir adalah finishing. Pada eksperimen 1 proses planner terdapat dilangkah ke tiga dan langsung planner untuk ke tiga sisi rotan agar menjadi rata.

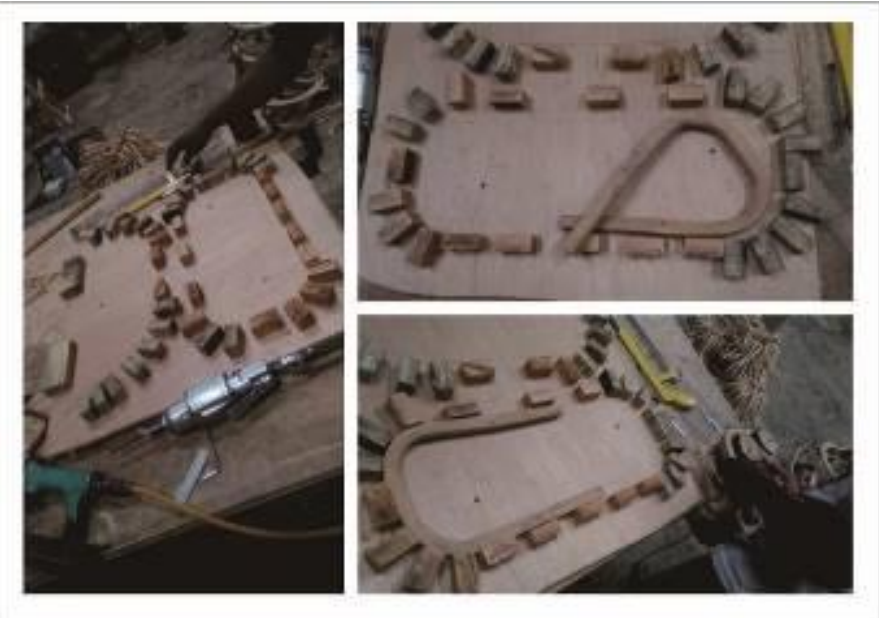

Gambar 8. Mal atau cetakan assembly untuk pembuatan amplifier rotan. Menggunakan ukuran yang sudah ditentukan di gambar teknik, lalu dibuat cetakannya dengan menyusun kayu sebagai pembatas rotannya.

\section{Eksperimen 2}

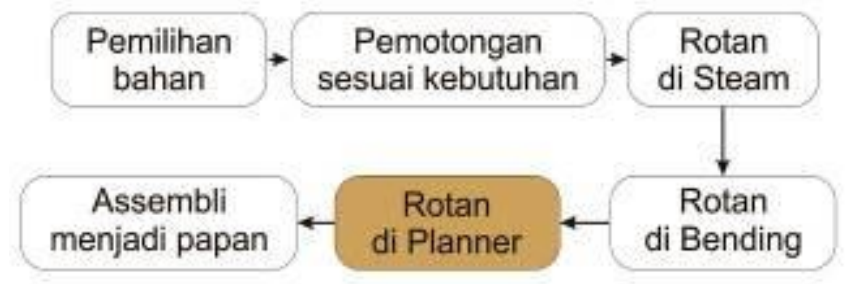

Gambar 9. Eksperimen pembuatan rotan 2.

Di eksperimen ke dua perbedaan terletak pada tahap proses planner dan bending. Pada eksperimen ini terjadi dua tahap proses planner, yang pertama proses planner untuk sisi atas saja, dan yang kedua proses planner untuk kedua sisi sampingnya.

Dilakukan eksperimen ini bertujuan untuk menemukan proses yang lebih efektif dalam proses produksi. Pada eksperimen pertama terjadi kecacatan pada rotan yang sudah di bending, terjadi lengkungan yang tidak diinginkan sehingga menyulitkan proses produksi.

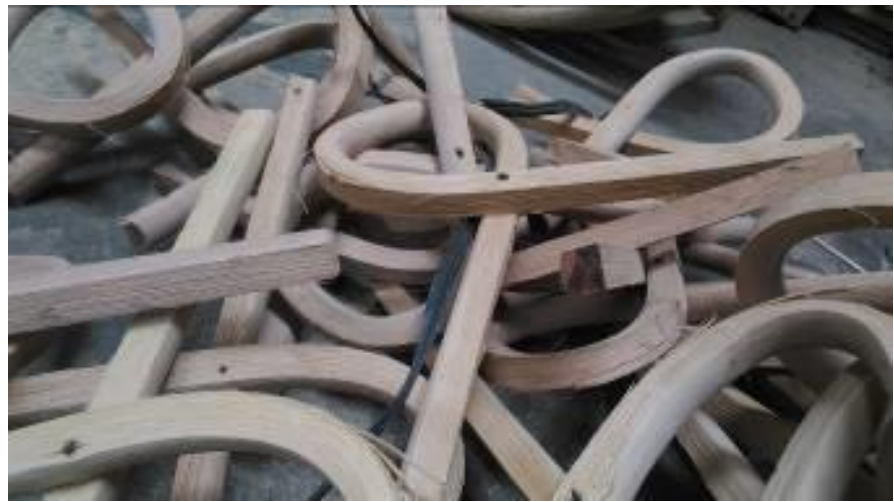

Gambar 10. Hasil Eksperimen 2 lebih efektif dibanding Eksperimen 1.

Dari kedua eksperimen tersebut dapat disimpulkan eksperimen kedua lebih efektif untuk proses produksi karena permukaan rotan yang dihasilkan tidak melengkung cacat seperti eksperimen pertama namun memiliki tahap yang lebih banyak dari eksperimen pertama.

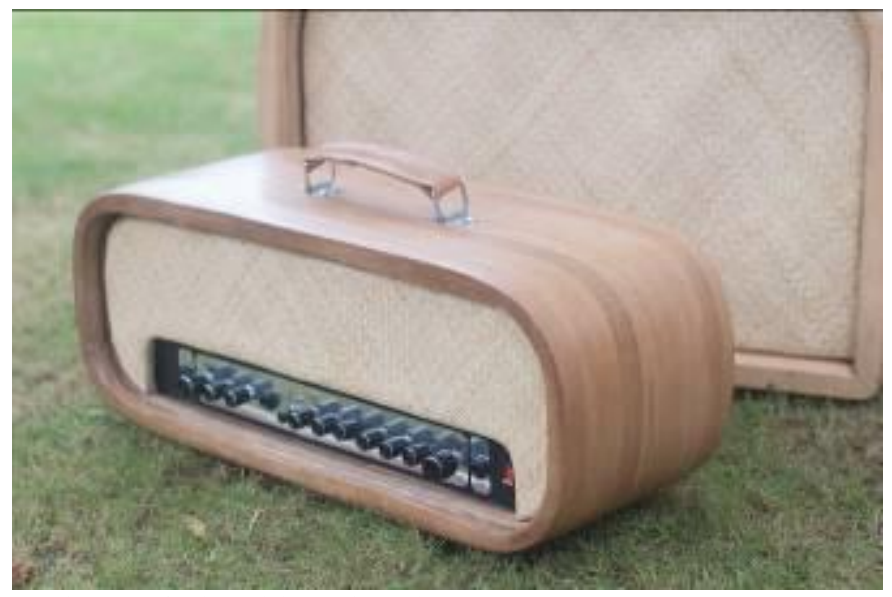

Gambar 11. Final Model Head Amplifier

\section{Tahap Branding}

Bentuk Logotype memiliki kesan elastis namun tegas dan saling berhubungan antar huruf dengan lainnya. Kata "Namo" sendiri diambil dari nama sebuah desa di Sulawesi Tengah yang sudah merawat kelestarian rotan sejak dulu yaitu Desa Namo.

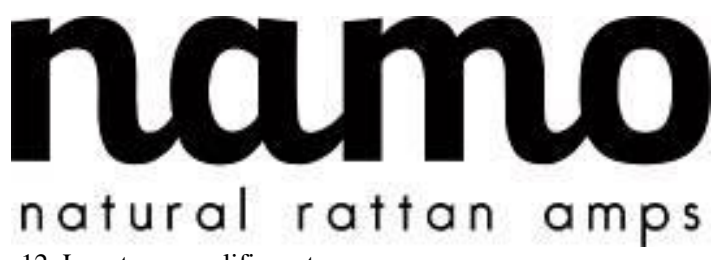

Gambar 12. Logotype amplifier rotan. 


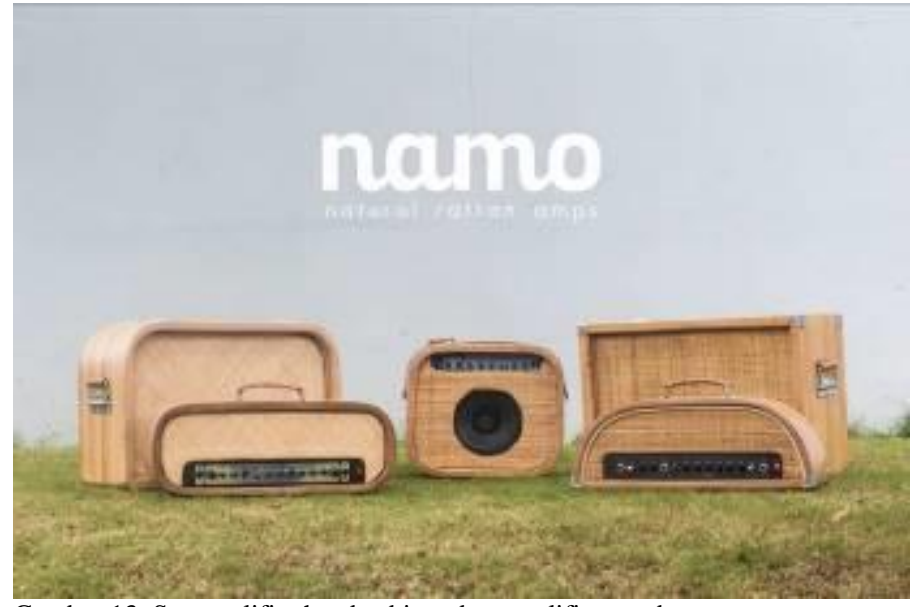

Gambar 13. Set amplifier head cabinet dan amplifier combo.

\section{Pengembangan Desain}

\section{Signature}

Signature adalah ciri khas dari suatu produk, yang biasa harus ada disetiap varian suatu produk. Maka pengembangan yang dilakukan harus mempertimbangkan signature yang sudah menjadi DNA dari produk tersebut.

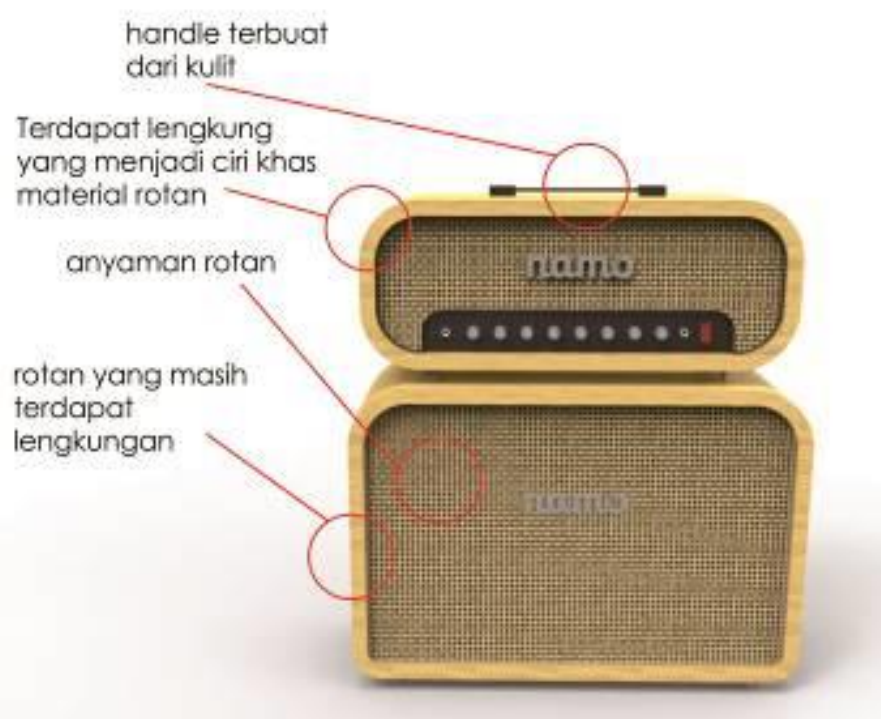

Gambar 14. Elemen signature dari Namo amps.

Pada pengembangan produk ini metode yang digunakan adalah metode pengembangan berdasarkan genre musik yang sedang berkembang karena setiap genre musik memiliki karakter persona yang berbeda-beda. Sebagai contoh adalah genre musik Jazz dan Rock, Jazz memiliki karakter persona yang lembut, calm, dan terkesan elegan. Sementara Rock memiliki karakter persona keras, garang, terkesan gagah. Akan tetapi harus tetap mempertimbangkan DNA dari produk Namo yang sudah dijelaskan sebelumnya.
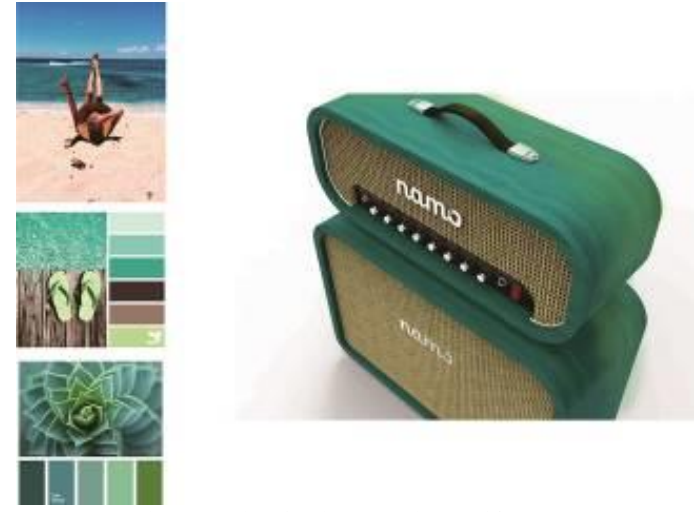

Gambar 15. Pengembangan desain dengan alternatif warna.
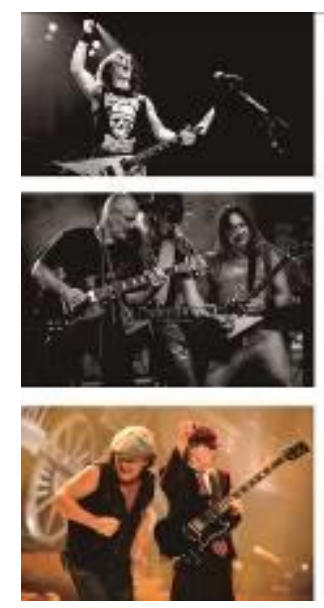

Gambar 16. Pengembangan desain dengan alternatif warna.

\section{KESIMPULAN/RINGKASAN}

A. Kesimpulan

1. Material Rotan sangat memungkinkan digunakan sebagai bahan dasar pembuatan box amplifier gitar, hanya saja harus dengan finishing yang lebih kuat agar rotan tidak mudah tergores

2. Bahan dasar rotan dengan metode bending akan sulit dan lama dalam proses pembuatannya, karena harus di assembly satu per satu.

3. Dibutuhkan komponen amplifier yang lebih baik untuk amplifier gitar, karena sangat berpengaruh pada karakter suara yang dihasilkan.

4. Setelah dilakukan analisis akustik rotan menggunakan metode tabung impedansi diketahui koefisien absorbsi rotan sangat tinggi pada frekuensi rendah, sedangkan dalam frekuensi tinggi absorbsi rotan menurun dan cenderung sangat rendah.

5. Dibutuhkan pengembangan produk dengan eksplorasi bentuk pada material rotan. 


\section{B. Saran}

1. Melakukan metode pengembangan produk sesuai yang sudah di rencanakan dalam bab sebelumnya, agar jenis dan seri produk dapat dikembangkan dengan baik.

2. Melakukan eksperimen menggunakan material alam lain untuk jenis produk baru dan tetap pada konsep natural yang telah dipakai.

3. Melakukan eksperimen dalam komponen elektronika, agar dapat digunakan dan diproduksi secara industri dengan merk sendiri.

4. Menyederhanakan proses pembuatan rotan pada produk, agar proses manufaktur lebih cepat prosesnya.

\section{DAFTAR PUSTAKA}

[1] Amplification, Marshall. 2016. Product List. Diakses dari https://marshallamps.com/ pada tanggal 27 november 2016 jam 08.00 $\mathrm{AM}$
[2] Amplification, Orange. 2016. Product List. Diakses dari https://orangeamps.com/ pada tanggal 27 november 2016 jam 08.00 $\mathrm{AM}$

[3] Hunter, Dave. 2013. 365 Guitar Amps \& Effect You Must Play. USA: Voyageur Press

[4] Hartono. 2013. Kemenperin Mendorong Pengembangan Industri Rotan Melalui Pendirian PIRNas. Jakarta: Kementrian Perindustrian RI.

[5] Arliansyah, Ferry. 2011. Mengenal Lebih Jauh Amplifikasi Gitar. Diakses

dari http://musicbandung.tumblr.com/post/11480194757/mengenal-lebihjauh-amplifikasi-gitar

[6] Stijl, Groene. 2009. Green Style. Belgium: booqs publishers bvba

[7] Biantoro, Ihsan. 2015. Eksplorasi Sistem Sambungan Rotan Pada Mebel Rotan. Surabaya: Laporan Studi Jurusan Desain Produk Industri FTSP-ITS

[8] Admin. 2016. Bagian Bagian Dari Power Amplifier dan Fungsinya. Diakses dari http://belajarelektronika.net/bagian-bagian-dari-poweramplifier-dan-fungsinya/ pada tanggal 2 Desember 2016 jam 06.00 PM

[9] Junaidy, Deny Willy. 2016. Inovasi Papan Dan Balo Rotan Laminasi. Diakses dari https://papanrotan.wordpress.com/author/rmeina/ pada tanggal 28 November 2016 Jam 09.00 AM. 